\title{
A Study of Hegemony and Class Conflict in Gaskell's North And South
}

\author{
Ziead Al-Khafaf \\ Atilim University, Turkey
}

\begin{abstract}
The paper discusses the relation between the north and south as two different geographical locations in the novel. By focusing on them, the article focuses on the hegemonic role of the classes and the emerging conflict. The conflict seems to be fought on industrial grounds but it relates to an intellectual and political awareness that plays a vital role in the sustenance of the ideological changes that take birth. The grave relationship of both classes is not controlled by sheer force but by a well thought out plan that plays a vital role delaying the emergence of a revolution in the working class. The void between the classes is sustained by a powerful mechanism which is indirectly ruling the entire arena of factories their workers and unions. Ironically the unions that are supposed to secure the lives and rights of the working class fall prey to the power of the industrialist.
\end{abstract}

Keywords: study, hegemony, class, conflict, Gaskell, north, south

\section{Introduction}

Elizabeth Cleghon Gaskell (1810-65) is known to be one of the most renowned authors in the history of English literature. Along with her other noteworthy subjects in work, her depiction of English country is life is quite well known among the critics. Gaskell posits the segregation between the two main social contributors, the rich and the poor, and also to the regions both classes belong, the modern and underdeveloped England. Therefore, Gaskell's subject matter not only discusses the hardlines between the North and South but also revisits the conceptual framework between a possible dialogue between these geographical locations in the widely divided English society of the time. The article revisits the dual perspectives of both sides and discusses the constant strife that exists within the settings of the novel. However, the focus will be Gramsci's idea of hegemony will be the underlining concept of the paper. The article focuses on Gramsci's theory of hegemony continued and sustained by cultural reasons, it is accompanied by the processes that control the societal values, and ideologies. At times the beliefs and practices are also controlled by the hegemonic deliverance of certain controlled mechanisms in the social infrastructure of the time.

\section{Discussion}

Antonio Gramsci (1891-1937), an Italian thinker, was a well-known activist during World War I and a leader of the Italian working-class struggle in the initial to middle 1920s, until his imprisonment on November 9, 1926. (Holub 3). After a long pause on the issues concerning Marx's ideas, Gramsci rose as a prominent name in the arena of Marxism. He particularly 
debates over the ideas of hegemony (Baker, 2000). Consistent ideas and criticism favour the submission of Gramsci's ideas overlapped by politics, institutional and civil society's responses. (Adamson 1983) Hegemony, according to Gramsci, is a group's dominance over affiliated and oppressed groups on a "cultural, moral, and ideological" level. (Gramsci, Selections from the prison notebooks 141-142). Gramsci's work relates to the changes after WWI in the Italian state. He believes that the workers were denied their rightful position and rights because of a widespread interaction of internal groups. The bourgeoisie stood with the state and so did the already unions. The oppression of workers continued in Italy unabased throughout the period and therefore an imminent workers' revolution failed to emerge on the surface and the union of capitalists supported by Trade unions and bourgeoisie emerged as the dominant group. (Morton 82). As an outcome, intellectual hegemony has emerged as the most powerful face of power. (Femia 1987) Which lacks in the lives of the people of different groups particularly relating to the working class.

Gaskell has lifelong experience confronting and dealing with the social affairs of the time. Gaskell's association and relation to industrial England are considerably deep. Born in Chelsea, Gaskell was the daughter of a civil servant. She spent her early years in Stratford-upon-theAvon, and later, visited other parts of the country meeting new people and relatives. In Manchester, Gaskell closely observed the life of the oppressed poor community whose experiences she mentioned in several of her writings. According to the Critic Robin B. Colby Gaskell belongs to the century that was riddled with change, and her writing is, particularly, a response to the changes happening in her life, and meanwhile, she brought change through her writings (qtd. in Nash 96). Jill L. Matus in his book The Cambridge Companion to Elizabeth Gaskell, considers Gaskell among the authors who were devoted to transform the world and bring change with the help of her pen. Her oeuvres were of real weight in the light of Victorian literary studies considering that she wrote masterpieces of diverse scope and variety in her writing career for about twenty-four years. Gaskell is thought to have a nurtured foundation in nineteenth-century Unitarianism, and she was open to constructive social transformations. Gender and class dynamics are addressed authoritatively in the setting of regional life and rising town life. As a result, modern critics equally acknowledge her intellectual excellence, acquaintance with scientific, economic, and religious research, and narrative creativity (1). However, Enid L. Duthi recognizes in Themes of Elizabeth Gaskell (1990) that Gaskell's works appear to be nostalgic. In reality, she was aware of the modest yet active country life. From haymaking through harvesting, apple collecting, and so on, all contain subtleties of her previous life compared to the then developing existence. Enid L. Duthi (1980) writes, "I long to be in those wild places again, with the fresh sea breeze round me" (10). Criticism of Elizabeth Gaskell's work has come a long way in the nearly fifty years since Lord David Cecil called her a" mild feminine Victorian" who" sees nothing but the flowers in the garden" of English rural life and whose industrial novels Mary Barton and North and South" (Martin 93) In comparison to Mary Barton, the South is frequently viewed as a subset of another issue. ( Bodenheimer, 1979) however, it can not be outrightly denied:

"By reclaiming the traditional mediating role of women's philanthropy in an environment where relations between the classes are based exclusively on the "cash nexus," Gaskell's novel represents a new social sphere that includes but is more than the domestic sphere of marriage, home, and children. Gaskell's woman visitor, however, has to contend with male professionals, especially clergymen, for access to and control of social space. Rejecting the South's social 
paternalism as nostalgic, Gaskell substitutes a new but still familiar metaphor for class relations: in place of the parent-child metaphor, she offers marriage." (Elliott, 1994)

Like many other consistent changes in the life of the main character her understanding of the social fabric and its dependency on the hegemony influencing it from different angles and institutions, remains the core of the plot. Gaskell's novel North and South portrays the protagonist Margaret Hale's life, who lives with her family in a small rural town known as Helstone. After the stay with her aunt in London, she arrives back in her small town and confronts a conundrum with her father, a church figure, who decides to leave Helstone on having a difference of opinion with the church authorities. As a consequence, Margaret and her family lose hope of finding no other source of earning other than tutoring in Helstone, so, the family decides to leave the small underdeveloped town and move to the flourishing and manufacturing industrial town of Milton. Mr. Thornton, a wealthy and successful Milton manufacturer, pays Mr. Hale to teach him classics. He goes to Mr. Hale regularly for his tutoring, where he meets Margaret Hales. Margret despises Thornton for his arrogant manner and brutal treatment of his manufacturing workers, whilst Thornton considers Margaret to be a snobbish woman. Mrs. Hale is recommended by the doctor to rest on a water bed after becoming unwell and feeling too weak. Given Mr. Thornton's goodwill to her father, Margaret begs his assistance in this situation and decides to borrow a waterbed.

When she reaches Thornton's house, she sees the factory workers are on a strike, disturbed by the introduction of Irish hands in factories as a source of cheaper labor as compared to the other Milton workers. She intends to help Thornton to calm out the protestors, but one of the agitators hits a stone on her head, leaving her unconscious. The protestors are subsequently dispersed and Mr. Thornton's Irish workers are left unharmed. Meanwhile, Margret and Thornton develop intense love for each other, but the circumstances do not allow the love to last forever. Following a series of severe financial disasters. Mr. Thornton, seeing no other alternative, intends to retire as a manufacturer. Margaret's financial situation, on the other hand, improves as a result of a bequest from her godfather. Margaret's decision to aid him with money later leads to the discovery of deep love sentiments on both sides.

North and South by Elizabeth Gaskell is a fascinatingly well-constructed notion of modern socioeconomic dynamics arising in England with the growth of industry and the capitalist economic system. It concentrates on the interrelationships between classes in their various ideological-cum-socioeconomic social contexts. The portrayal of the deep interest conflicts between employees and masters significantly enhances the narrative's center. The characters like Margret are inferior and oppressed, while on the other hand, the characters like Mr. Thornton are exploiters or a dominant class benefiting from the subaltern class. Inspired by Marxism, Gaskell intended to portray a materialistic theme of class struggle. There are two major class relations, the poor earning to survive and the rich continuously struggling to secure a dominant position. The rich are exploitations, who hire laborers and pay them less than they deserve.

The narrative involves a comparison of the North and South as geographical places with vastly different attitudes to living. People from the north are more active and passionate for material supremacy, whilst Southerners are content to live a modest existence. Gaskell extensively analyses the situations of both sections by introducing Margaret as an intermediating figure and, to some extent, a round character, referring to the class struggle as a "Battle." Gaskell shows both sides of the picture and brings peace at the end. She contributes to the 
investigation on the one hand by revealing the working class' terrible conditions, health complications, pitiful wages, unrest, and enslavement, and on the other hand by carefully examining the Bourgeoisie battle and quest for success, as well as their harsh stance on the disputes. Also, we can integrate Gramscian theory of hegemony to Gaskell's North and South, as defined by Gramsci as a group's "cultural, moral, and ideological" leadership over oppressed and inferior groups. In the North and South, we observe the industry owners dominate the proletariat class and there is extreme exploitation of laborers triggering protests and unrest. In the North and South, geographic location as well play a major figurative role, for instance, both North and South are poles apart, symbolize economically and socially unlike disconnected parts of England. Likewise, the critics find out that there are two dissimilar, and yet geographically and historically significant faces of England. Such two distinct parts also portray the importance of class structure and how they are formed by the difference in economic activities in a certain society.

However, one of the important aspects of the class distinction is the debate over their differences in terms of class consciousness, dealing with certain matters, and values adhering to the class structure. Margret accuses industrialization in the capitalist country of creating such a major difference in class attitudes. Gaskell stresses over the failure drawn within the lives of the people living in the North and as well as the South. In other words, she examines issues from a microscopic perspective so that the issues raised by Milton may be examined in greater depth and detail. Throughout history, various commentators and authors have passionately discussed this split inside the country, which encompasses both social and economic elements.

The people belonging to North at Gaskell's time were generally admired as being hard workers and diligent because they were more exposed to the industrial revolution in England. The inhabitants of the south, on the other hand, were seen to be polar unlike the people of the north. According to Mrs. Thornton, "south country people are sometimes terrified by what Darkshire or North men and women merely term living and suffering" (136).

The town of Milton is a perfect portrayal of such class differences; with the representation of the downtrodden northern class by Margret and the dominant southern class by Mr. Thornton. In the process, the author indirectly refers to the dispute as the result of several factors. Most significantly, she criticizes the concept of uncontrolled progress without regard for the lowerclass or poor, which would result in more difficult situations and agony for mankind rather than alleviation.

Therefore, she somehow does not appear to regard the rise of industrialization as a negative factor. The writer neither supports nor opposes industrialization. In reality, Gaskell appears to establish peace amongst the socioeconomic groups living in the industrial period. The author employs poetry to inform the reader on the need for reforms, and she sees class conflict as an unavoidable result. She conveys the sense that the threats will persist until everyone involved adopts a more practical and rational approach. The poetry and quotes at the opening of several chapters include important information. Thornton refers to the clash of classes as a "battle," while his mother refers to it as a "fight." Mrs. Thornton likewise refers to the predicted worker unrest as "their next attack" (137). To put it another way, Milton appears to be a specimen of capitalist economic culture in which existence is solely reliant on citizens' earning impulses and skills. Survival might be thought of as survival of the fittest. Mr. and Mrs. Thornton are hegemons, leading subaltern groups by ideology and utilizing their hard work 
for their benefit. The capitalist group is dominating the oppressed group, and yet, there is an ongoing fight for survival. The dominant and acceptable canon of society under which the weaker are supposed to be crushed is success for the strong and cunning. Mr. Thornton feels that individuals who suffer much as a result of financial issues should look within themselves for flaws, while those who work hard will achieve a respected position (97-101). In the words of Margaret, Gaskell emphasizes to readers that all individuals who fail to raise themselves are not undeserving of it, because people differ in their surroundings, opportunities, and physical and mental talents (97). Likewise, Mr. Thornton's support for the capitalist class is presented sarcastically by the writer when the death of his father, caused by despair over large financial losses, is disclosed.

Marx negated the theory of natural harmony stating that the eighteenth century marks the beginning of polarization and the split of social classes into two main groups: oppressor and the oppressed, due to disparities between the propertied and non-propertied classes. The bourgeoisie class formed as a result of a prior struggle-among the capitalistic forces and feudal relations. Later on, the class formed the "superstructure" by setting clear goals and objectives and its domination on the society. In a capitalist society, the shifting means of production led to the fall of the proletariat. According to Marx, the industrial community would experience certain expected changes and eventually progress through several stages of evolution, culminating in a worldwide proletariat revolution. According to these stages, the bourgeoisie or middle class will decline in number, workers will rise in number, and all other intermediary groups will lose substantial political influence, polarising society between two powers, the bourgeoisie and the proletariat. That does not mean that other social classes, such as feudal nobles, peasants, the middle class, or manufacturers, will be extinguished. They simply do not have any relevance in the production relations, nor do they have any sense of class. They have not acclimated to the contemporary environment and lack awareness of the enemy. The clash between the bourgeoisie and the proletariat then dominates society. It occurs in many aspects of social life, including economics, culture, politics, and ideology. The struggle is a historical rule and a factor that accelerates growth in all societies where hostile classes compete for a greater position in the production process. Both the bourgeoisie and the proletariat have competing interests that cannot be resolved without modification. Marx referred to this situation of social conflict as "a contradiction." According to Marx, the primary cause of the conflict is the different connections of each class to the means of production. The capitalist structure of the industry, which contributed to the emergence of the forces of production, has begun to stifle the latter, resulting in an irresolvable struggle between possessors and non-possessors, which is embodied in the differing demands and aspirations of both classes. Within the social connections, the objective conflict in the economic position has a subjective equivalent. These elements begin to diverge to the point that they can no longer be reconciled in a peaceful, evolutionary manner (Wright 61-89).

Margaret refers to this conflict as a collision of interests, and via her, Gaskell appears to educate the reader that the roots of the strife are not evil and can be addressed with tolerance and the equal involvement of both groups, namely the labor and bourgeois classes. Furthermore, the class dependency in Milton is the reason for the torments resulted due to miserable living conditions. To her clash is the consequence of the interests of both of the classes that are reluctant to negotiate "yet each evidently regarding the interests of the other as opposed to their own; I never lived in a place before where there were two sets of people always running each other down" (139-41). 
The Milton elite class can be considered as a hegemon class, which is indisposed to grant any sort of lucre to the hardworking factory workers, whereas, the oppressed laborers demand rights considering their pitiable life situation, by and large as a result of meagre wage pay rates, "they've been paying these two years past and flourishing upon and getting richer upon" (157). However, Gaskell portrays in the shape of Margret's viewpoints, that the breach between the poor and the rich resulted from materialistic differences, and inequalities embedded in the class structure are the forces behind the glitches. The narrative seems like Gaskell does not advocate or recommend any of the classes, but she discusses the differences to bring a positive result at the end. Julie Nash in her

Gaskell has portrayed class conflicts using Margret as a medium in the best possible manner. Initially, Margret acts as a mediator between the conflicting parties. With her leading character in the novel, Margret appeals to the readers and critics in the way she changes herself what she goes through. She spends her life in both of the cities, Helstone and London, and her settlement in Milton brings a conflict both within the society and herself. Margret can be taken as an innocent character with an ideology who struggles to change while she is challenged by her harsh living conditions.

Additionally, we can observe both North and South regions, and her perception changes when she spends days with her aunt in London when she is challenged by the poor living circumstances in the north. As a young girl, she saw living on Harley Street as a brief visit that cannot be a lifelong substitute for her life in the town where she may experience the essence of independence in all aspects of life. Similarly, amid the commotion, she represents both sides.

In the later part, Margret realizes that the workers' community is being treated unfairly by the industrial capitalist class. She tells Mr. Thorton, “Don't let the army cut down the poor men who are driven mad" (209), and also, she falls unconscious when hit by a stone while the protest is going on. At first, she feels that inequalities are so blatant and that employees are indeed being mistreated, but as the story progresses, she comes to respect Milton's life. In other words, Margaret's ideological being transforms significantly during the process as she begins to appreciate the hard work and dedication of factory owners in general and Mr. Thornton in particular.

Karl Marx introduced the idea of historical materialism linking human progress with material means of production questions the role of mankind in historical development. Marx has the clear answer, stating that the societal histories, being in the process of a constant change in the means of production, is, therefore, a history of the forces contributing to the manufacturing of the material goods. Despite exploitative working conditions, the people are always the evolutionary force, both in economical and political spheres, transforming and developing the means of production (Helemejko 14). The proletarians need guidance in their path of history. In this pursuit of defining historical developments, Marx neither decreased nor negated the importance of humankind. The more people actively participate in events transforming history the more they demand politicians, leaders, and ideologists. Marx's suggested their crucial role in the growth of the conscience of the excelling class. Even though he emphasized the significance of such unique individuals appearing at pivotal periods in history, but he ignored any indications of an individual cult as utopian ideas (Helemejko 14).

The term hegemony, derived from the Greek word "eugemonia", literally means "the dominant and dictatorial status of one element in the system over the other." The notion of hegemony makes it possible to have a better grasp of current international relationships and power 
structures. Antonio Gramsci has made major contributions to the formulation of this notion, arguing that power is reliant not just on force but also on 'consent.' Gramsci defines hegemony as the position of the most powerful country in the world system or the position of a dominant state in a given region. Hegemony, according to Gramsci, includes "cooperation ensured by force," combining social and political surveillance, coercion, and consent (Simon 103). Gaskell has excellently portrayed the perception of hegemony in the North and South, where one class suffers and the other spends a lavish life.

North and South is an incredible depiction of industrial capitalism and the hegemonic role of England in the 1840s to 1850s when the world was in the rush of the industrial revolution. In simple terms, according to Gramsci, hegemony is the dominance of one group over another, and the dominant group is richer and fittest, on the other hand the subordinate group is weaker and downtrodden. In North and South, we observe the exploitation of the working class, whereas, in the latter part, the uprisal of the laborers is an unavoidable consequence. Mr. and Mrs. Thornton's characters are associated with industrial hegemonic power dynamics and Marxist depiction of a wealthy capitalist class. The characters show many emblems of how hegemonic power structures penetrate industrial societies, and the low-income families are forced to work for a meager per day wage. Margret's character is visionary, she observed everything and is well-aware of the drawbacks of hegemonic capitalist nations.

The narrative also shows a disturbing relationship between the master and the working for the reason both have extremely different lifestyles and demands from life. The elite hegemon tries to secure his powerful position by utilizing laborers' hard work and the downtrodden struggles to be paid a little more than his current pay rate. The laborers find no platform to submit their demands and seek justice, so they end up an uprising against their master by protesting and stopping the factory work. However, because the owners have more influence over the superstructure due to their better monetary position, they intend to smash the revolt with the assistance of state-run machinery, i.e., the army, compelling the people to abandon their revolt. Here, the involvement of the army is another symbol of hegemonic power structures. As a result, Althusser claims, the army is utilized as a (repressive) State Apparatus (1492). As a result, the hegemonic grip on institutions, notably laws and bureaucratic organs, supports the ruthlessness that may be employed against workers protesting long-standing injustices. Similarly, there is always the dominance of monetary considerations acting as a fault line, particularly when it comes to legislation. According to Gaskell, unrest simmers because employees desire more rights, a lot of self-esteem, and ownership, but factory owners dismiss the protestors as a gang of ungrateful dogs seeking more salaries (137).

The theory of hegemony by Antonio Gramsci is essentially a critique of the way of thinking that lowers and believes the essence of identity to be the sole absolute truth, particularly the reductionism and essentialism found in Marxist and Non-Marxist concepts. The ideas of fundamental structure (economics) and superstructure (ideology, politics, education, culture, and leadership) have been debated among Marxists, with the view of Classical Marxism believing that the economy's underlying framework dictates the superstructure. The class struggle was limited to merely an economic class war, while other movements such as the civil rights movement, women's movements, cultural movements, environmental movements, and other social movements were neglected (Simon 103).

The full spectrum of communication and academic possibilities are confined in the lives of the ruling class to the goal of learning the art of earning as much as possible. Producers enrolled 
their boys in institutions at a young age in the hopes of getting maximum benefit in the shape of increased vigor for commerce and money earning and maintaining a high standing among the town's businessmen. The elite hegemonic class is trained in such a way to win the economic race without which they would be a misfit. The children of the dominant class are trained from their schools to dominate the entire economic system. North and South by Gaskell is an excellent portrayal of hegemonic power relations, where there is a large difference between both the classes, the oppressed and the oppressor.

\section{References}

[1] Adamson, Walter L. Hegemony and Revolution: A Study of Antonio Gramsci's Political and Cultural Theory. Univ. of California Press, 1983.

[2] Baker, James R. "Golding and Huxley: the fables of demonic possession." TwentiethCentury Literature 46.3 (2000): 311-327.

[3] Bodenheimer, R. (1979). North and South: A Permanent State of Change. NineteenthCentury Fiction, 34(3), 281-301

[4] Duthie, Enid L. The Themes of Elizabeth Gaskell. Springer, 1980.

[5] Elliott, D. W. (1994). The Female Visitor and the Marriage of Classes in Gaskell's North and South. Nineteenth-Century Literature, 49(1), 21-49.

[6] Femia, Joseph V. "The Revolutionary PARTY: Architect of the New Hegemony." Gramsci's Political Thought, 1987, pp. 130-164., doi:10.1093/acprof:oso/9780198275435.003.0004.

[7] Gaskell, Elizabeth Cleghorn. North and south. Penguin, 1995.

[8] Gramsci, Antonio. "Selections from the Prison Notebooks." The Applied Theatre Reader, 1971, pp. 141-142., doi:10.4324/9780429355363-27.

[9] Gramsci, Antonio. Prison Notebooks Volume 2. Vol. 2. Columbia University Press, 2011.

[10] Hartley, Will, and Renate Holub. "Antonio Gramsci: Beyond Marxism and Postmodernism." Italica, vol. 71, no. 2, 1994, p. 245., doi:10.2307/480018.

[11] Helemejko, Tomasz. "The concept of Marxism." (2012).

[12] Martin, C. A. (1983). Gaskell, Darwin, and" North and South". Studies in the Novel, 15(2), 91-107.

[13] Matus, Jill L., ed. The Cambridge Companion to Elizabeth Gaskell. Cambridge University Press, 2007.

[14] Morton, Adam David. "Unravelling Gramsci: Hegemony and Passive Revolution in the Global Pol.” 2015, doi:10.2307/j.ctt18dzstb.

[15] Simon, Roger, et al. Gagasan-gagasanpolitik Gramsci. Pustaka Pelajar: Institute for Social Transformation (Insist), 1999.

[16] Wright, Erik Olin, Andrew Levine, and Elliott Sober. Reconstructing Marxism: Essays on explanation and the theory of history. Verso, 1992. 